\title{
Xanthine oxidase inhibitor tungsten prevents the development of atherosclerosis in ApoE knockout mice fed a Western-type diet.
}

Citation for published version (APA):

Schroder, K., Vecchione, C., Jung, O., Schreiber, J. G., Shiri-Sverdlov, R., van Gorp, P. J. J., Busse, R., \& Brandes, R. P. (2006). Xanthine oxidase inhibitor tungsten prevents the development of atherosclerosis in ApoE knockout mice fed a Western-type diet. Free Radical Biology and Medicine, 41(9), 1353-1360. https://doi.org/10.1016/j.freeradbiomed.2006.03.026

Document status and date:

Published: 01/01/2006

DOI:

10.1016/j.freeradbiomed.2006.03.026

Document Version:

Publisher's PDF, also known as Version of record

Document license:

Taverne

Please check the document version of this publication:

- A submitted manuscript is the version of the article upon submission and before peer-review. There can be important differences between the submitted version and the official published version of record.

People interested in the research are advised to contact the author for the final version of the publication, or visit the DOI to the publisher's website.

- The final author version and the galley proof are versions of the publication after peer review.

- The final published version features the final layout of the paper including the volume, issue and page numbers.

Link to publication

\footnotetext{
General rights rights.

- You may freely distribute the URL identifying the publication in the public portal. please follow below link for the End User Agreement:

www.umlib.nl/taverne-license

Take down policy

If you believe that this document breaches copyright please contact us at:

repository@maastrichtuniversity.nl

providing details and we will investigate your claim.
}

Copyright and moral rights for the publications made accessible in the public portal are retained by the authors and/or other copyright owners and it is a condition of accessing publications that users recognise and abide by the legal requirements associated with these

- Users may download and print one copy of any publication from the public portal for the purpose of private study or research.

- You may not further distribute the material or use it for any profit-making activity or commercial gain

If the publication is distributed under the terms of Article 25fa of the Dutch Copyright Act, indicated by the "Taverne" license above, 


\author{
Original Contribution
}

\title{
Xanthine oxidase inhibitor tungsten prevents the development of atherosclerosis in ApoE knockout mice fed a Western-type diet
}

\author{
Katrin Schröder ${ }^{\mathrm{a}}$, Carmine Vecchione ${ }^{\mathrm{b}}$, Oliver Jung ${ }^{\mathrm{c}}$, Judith G. Schreiber ${ }^{\mathrm{a}}$, \\ Ronit Shiri-Sverdlov d, Patrick J. van Gorp ${ }^{\mathrm{d}}$, Rudi Busse ${ }^{\mathrm{a}}$, Ralf P. Brandes ${ }^{\text {a,* }}$

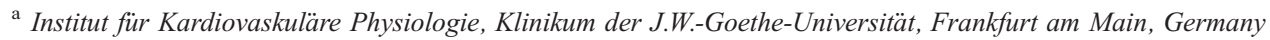 \\ ${ }^{\mathrm{b}}$ Neuromed, Pozzili, Italy \\ ${ }^{\mathrm{c}}$ Medizinische Klinik IV, Funktionsbereich Nephrologie, Klinikum der J.W.-Goethe-Universität, Frankfurt am Main, Germany \\ ${ }^{\mathrm{d}}$ Department of Molecular Genetics, University Maastricht, Maastricht, The Netherlands
}

Received 8 June 2005; revised 9 March 2006; accepted 15 March 2006

Available online 4 April 2006

\begin{abstract}
Hyperlipidemia enhances xanthine oxidase (XO) activity. XO is an important source of reactive oxygen species (ROS). Since ROS are thought to promote atherosclerosis, we hypothesized that $\mathrm{XO}$ is involved in the development of atherosclerosis. ApoE ${ }^{-/-}$mice were fed a Western-type (WD) or control diet. In subgroups, tungsten $(700 \mathrm{mg} / \mathrm{L})$ was administered to inhibit XO. XO is a secreted enzyme which is formed in the liver as xanthine dehydrogenase $(\mathrm{XDH})$ and binds to the vascular endothelium. High expression of $\mathrm{XDH}$ was found in the liver and WD increased liver XDH mRNA and XDH protein expression. WD induced the conversion of XDH to the radical-forming XO. Moreover, WD increased the hepatic expression of CD40, demonstrating activation of hepatic cells. Aortic tissue of ApoE ${ }^{-/-}$mice fed a WD for 6 months exhibited marked atherosclerosis, attenuated endothelium-dependent relaxation to acetylcholine, increased vascular oxidative stress, and mRNA expression of the chemokine KC. Tungsten treatment had no effect on plasma lipids but lowered the plasma XO activity. In animals fed a control diet, tungsten had no effect on radical formation, endothelial function, or atherosclerosis development. In mice fed a $\mathrm{WD}$, however tungsten attenuated the vascular superoxide anion formation, prevented endothelial dysfunction, and attenuated KC mRNA expression. Most importantly, tungsten treatment largely prevented the development of atherosclerosis in the aorta of ApoE ${ }^{-/-}$mice on $\mathrm{WD}$ Therefore, tungsten, potentially via the inhibition of $\mathrm{XO}$, prevents the development of endothelial dysfunction and atherosclerosis in $\mathrm{ApoE}^{-/-}$ mice on WD.
\end{abstract}

(C) 2006 Elsevier Inc. All rights reserved.

Keywords: Oxidative stress; Atherosclerosis

\section{Introduction}

Reactive oxygen species (ROS) have been implicated in the development of atherosclerosis [1]. ROS promote the oxidation of lipids, rendering them more atherogenic, and ROS react with and destroy NO. Peroxynitrite is one product of the reaction of NO with the radical superoxide anion $\left(\mathrm{O}_{2}^{-}\right)$, which is a strong oxidant that contributes to the inactivation of

Abbreviations: DHE, dihydroethidium; PCR, polymerase chain reaction; ROS, reactive oxygen species; VLDL, very-low-density lipoprotein particles; $\mathrm{WD}$, Western-type diet; XDH, xanthine dehydrogenase; XO, xanthine oxidase.

* Corresponding author. Fax: +496963017668.

E-mail address: r.brandes@em.uni-frankfurt.de (R.P. Brandes). proteins [1]. Exposure to ROS changes the vascular gene expression, leading to the production of chemokines and adhesion molecules as well as to cellular proliferation or hypertrophy [2].

Despite this strong rationale for an important role of ROS in atherosclerosis development, clinical evidence is still lacking to show that ROS scavenging prevents progression of atherosclerosis $[3,4]$. Possible explanations for the failure of antioxidative therapy are the highly adaptive responses of the antioxidative defense system and the compartmentalization of ROS signaling. A more specific and mechanistic approach to elucidate the role of ROS in the development of atherosclerosis might be the inhibition of ROS-generating enzymes. Several enzyme systems are thought to contribute to vascular oxidative stress. 
Beside mitochondria, cytochrome P450 monoxygenases, and an uncoupled endothelial NO synthase, particularly xanthine oxidase and NADPH oxidases are thought to be sources of vascular oxidative stress [1]. Although NADPH oxidases are potent generators of ROS, the three studies performed in NADPH oxidase/ApoE double knockout mice yielded conflicting results. One study reported a significant reduction in the extent of atherosclerosis in the abdominal aorta of p47phox/ApoE double knockout mice [5], whereas further studies performed in p47phox/ApoE [6] and in gp91phox/ApoE double knockout mice [7] failed to demonstrate a difference in the extent of atherosclerosis between $\mathrm{ApoE}^{-/-}$strains with and without NADPH oxidase activity.

Several studies performed in man and animals suggest that hyperlipidemia increases xanthine oxidase (XO) activity [8-10]. It is, however, not known, whether $\mathrm{XO}$ contributes to the development of atherosclerosis [1].

The aim of this study therefore was to determine whether inhibition of XO prevents the development of atherosclerosis. In order to test this hypothesis, $\mathrm{ApoE}^{-/-}$mice were fed a Westerntype diet and $\mathrm{XO}$ was inhibited pharmacologically. $\mathrm{ApoE}^{-/-}$ mice are a standard model for atherosclerosis development [11] and a Western-type diet enhances the development of plaques in this strain. A study using XO knockout mice is not feasible as these animals die at the age of 6 weeks [12].

XO catalyzes the conversion of hypoxanthine to xanthine and from xanthine to urate. While under physiological conditions, the enzyme is active primarily as a dehydrogenase $(\mathrm{XDH})$; several stimuli such as inflammation and hypoxia promote the conversion of $\mathrm{XDH}$ to the superoxide-producing $\mathrm{XO}$ [10]. Allopurinol is widely used to inhibit $\mathrm{XDH} / \mathrm{XO}$, also in humans. In mice, however, allopurinol is highly nephrotoxic [13] and therefore not suitable for long-term treatment. Therefore, tungsten was used in the present study to inhibit $\mathrm{XO}$ activity. This heavy metal prevents incorporation of molybdenum into the active center of $\mathrm{XDH} / \mathrm{XO}$ and impairs the de novo synthesis of active enzyme [14-16].

\section{Methods}

\section{Study design and animal procedures}

$\mathrm{ApoE}^{-/-}$mice were purchased from Taconis M\&B A/S (Ry, Denmark, strain B6.129P2-Apoe $\left.e^{t m 1 U n c} \mathrm{~N} 6\right)$ and bred at the local animal care facility. Western-type ( $42 \%$ of total calories from fat; $0.15 \%$ cholesterol) diet was purchased from Harlan Teklad Germany (Harlan Winkelmann, Borchen, Germany); control chow was from Altromin (Lage, Germany, brand Altromin 1324). Experiments conformed to the Guide for the Care and Use of Laboratory Animals published by the U.S. National Institutes of Health (NIH Publication No. 85-23) and were approved by the local government (II25.3-19c20/15-F28/02).

Animals were started on Western-type diet at the age of 12 weeks and sacrificed after a feeding period of 6 months. A subgroup received tungsten with the drinking water $(700 \mathrm{mg} /$ L sodium tungstate dihydrate, Sigma-Aldrich) as reported previously [15].

\section{Organ chamber experiments}

Organ chamber experiments were performed as described previously using mouse aortic rings [17]. The concentration of phenylephrine was adjusted to obtain an identical preconstriction level of $80 \%$ of the contraction elicited by $\mathrm{KCl}(80 \mathrm{mmol} / \mathrm{L})$ and endothelium-dependent relaxation was determined by the application of cumulative doses of acetylcholine (ACh, $0.1 \mathrm{nmol} / \mathrm{L}-10 \mu \mathrm{mol} / \mathrm{L}$ ). No statistical difference was observed in the preconstriction level and force development of the different study groups (data not shown).

\section{Vascular radical generation}

In situ $\mathrm{O}_{2}^{-}$levels were assessed using the fluorescent probe dihydroethidium (DHE) as described previously [18]. Briefly, aortae were dissected, cut into $1-\mathrm{cm}$ rings, and embedded in OTC Tissue Tek (Sakura) and frozen using liquid nitrogencooled isopentane. Cryosections of the rings $(7 \mu \mathrm{m})$ were placed on glass slides and DHE $(10 \mu \mathrm{mol} / \mathrm{L})$ was applied topically for $30 \mathrm{~min}$. Subsequently fluorescent images were obtained using a confocal microscope ( $\lambda$ Ex: 488, Em: 585 nm; Carl Zeiss LSM 510 meta).

\section{Immunoblotting}

Western blot analysis from Triton X-100 (1\%)-soluble protein was performed as described previously [18] using a rabbit anti-mouse xanthine dehydrogenase/oxidase antibody, kindly provided by J. McManaman (University of Colorado Health Sciences Center, Denver, CO) [19].

\section{Xanthine oxidase activity}

Activity was determined using a previously described fluorimetric assay which is based on the XO-catalyzed conversion of pterin (2-amino-4-hydroxypteridine, $10 \mu \mathrm{mol} / \mathrm{L}$ ) to the fluorochrome isoxanthopterin (excitation $345 \mathrm{~nm}$, emission $390 \mathrm{~nm}$ ) [20]. XO activity was determined from $50 \mu 1$ of serum and calibrated using a standard curve generated with authentic isoxanthopterin (Sigma). Measurements were performed in a final volume of $600 \mu \mathrm{l}$ in phosphate buffer $\left(\mathrm{K}_{2} \mathrm{HPO}_{4} / \mathrm{KH}_{2} \mathrm{PO}_{4} 50 \mathrm{mmol} / \mathrm{L}\right.$; EDTA $0.1 \mathrm{mmol} / \mathrm{L} ; \mathrm{pH}$ 7.4). Pterin $(1 \mathrm{mmol} / \mathrm{L})$ was prepared fresh everyday as a stock solution in $1 \mathrm{mmol} / \mathrm{L} \mathrm{NaOH}$.

\section{Real-time PCR}

Primers against mouse $\mathrm{XDH}, \mathrm{KC}, \mathrm{CD} 40$, and CD40 ligand were designed using the sequence information of the NCBI database. The following primers were used: $\mathrm{XDH}$, forward 5'-ATCTGGAGACCCACTGCACC-3' and reverse 5'-TGTGCTCACGAAGAGCTCCAT-3'; KC, forward 5'TGCGAAAAGAAGTGCAGAGA- $3^{\prime}$ and reverse 5'-CGAGACGAGACCAGGAGAAA-3'; CD 40, forward 5'-CGGTCCATCTAGGGCAGTGT-3' and reverse 5'CTGGCTGGCACAAATCACAG-3'; CD40 ligand, foward 
5'-TCGGGAGCCTTCGAGTCA-3' and reverse 5'GATCCACTGCTGGGCTTCAG-3', 18S, forward 5'CTTTGGTCGCTCGCTCCTC-3' and reverse $5^{\prime}$ CTGACCGGGTTGGTTTTGAT-3'. Total RNA was isolated from mortared liver samples and aortic rings using the Absolutely RNA RT PCR Miniprep kit (Stratagene Europe) and the extracted total RNA (between 250 and $350 \mathrm{ng}$ ) was used for reverse transcription (Superscript II or III RT, Invitrogen) with pdN6 or oligo(dT) primers (Amersham/Pharmacia) in a total volume of 50 or $20 \mu \mathrm{l}$. Aliquots of the RT reaction were analyzed using an MX4000 real-time PCR machine (Stratagene) with the oligonucleotides described, platinum Taq polymerase (Invitrogen), and SYBR green I according to the manufacturer's instructions. The PCR conditions were as follows: initial denaturation: $95^{\circ} \mathrm{C}, 10 \mathrm{~min} ; 40-45$ cycles of denaturation $\left(95^{\circ} \mathrm{C}, 30 \mathrm{~s}\right)$, annealing $\left(55-67^{\circ} \mathrm{C}, 30-60 \mathrm{~s}\right)$, and elongation $\left(72^{\circ} \mathrm{C}, 30-60 \mathrm{~s}\right)$. Data were normalized against $18 \mathrm{~S}$ mRNA expression using the $\Delta \Delta \mathrm{CT}$ method.

\section{Plaque area}

The abdominal aorta was cleaned of connective tissue, cut open longitudinally, and photographed using a CCD camera attached to a stereomicroscope (Leica). Vessel surface area and plaque surface area were determined using the $\mathrm{PC}$ version of NIH image (Scion Corp) in a blinded fashion, and relative plaque area was calculated.

\section{Plasma lipid parameters}

Lipoprotein profiles were determined on plasma samples from 24 (5-6 per group) mice using an AKTA Basic chromotography system with a Superose 6PC 3.2/30 column (Amersham Biosciences, Roosendaal, the Netherlands) as described previously in detail [21]. Blood samples were treated with the paraoxon during collection (to prevent free fatty acid degradation). After collection, the samples were kept on ice, centrifuged at $4^{\circ} \mathrm{C}$ for $20 \mathrm{~min}$ at $4000 \mathrm{rpm}$, and snap-frozen in liquid nitrogen. Plasma cholesterol and triglyceride levels were measured using a commercially available kit (1489232, Chol CHOD-PAP, Roche, Almere, the Netherlands; 337-B, TG GPO-trinder, Sigma Aldrich, Zwijndrecht, the Netherlands). Measurements were done according to manufacturer's protocols on a Benchmark $550 \mathrm{~nm}$ microplate reader (170-6750XTU, Bio-Rad, Veenendaal, the Netherlands).
A

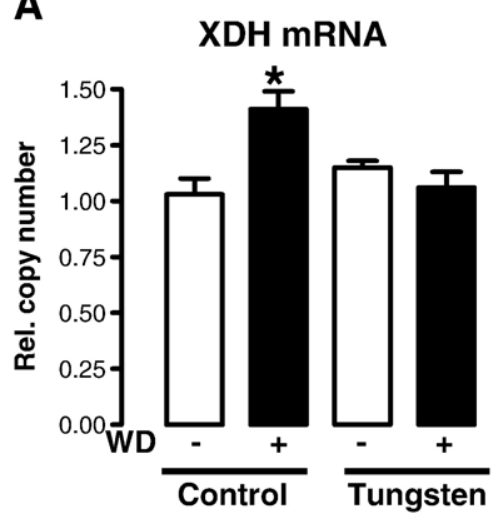

C

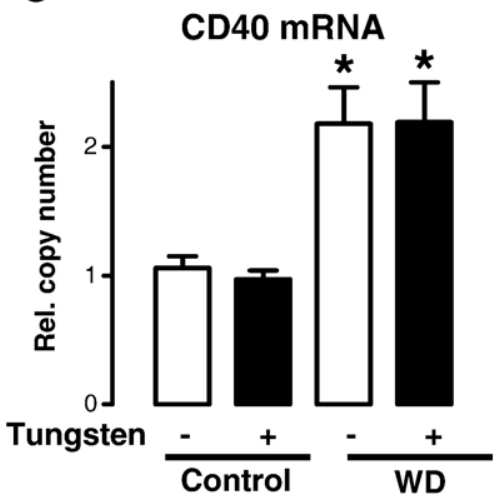

B

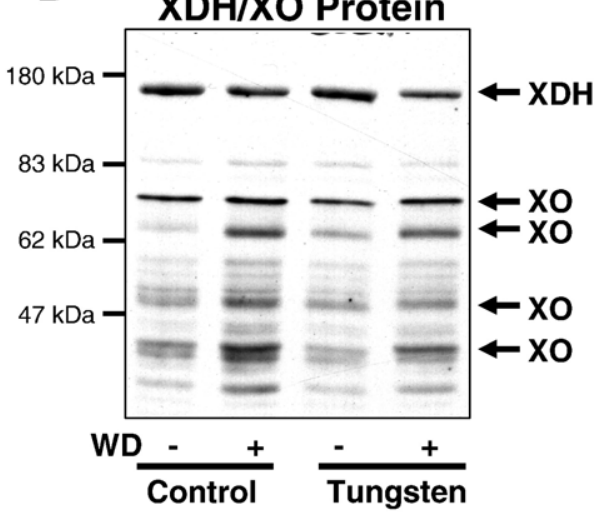

D
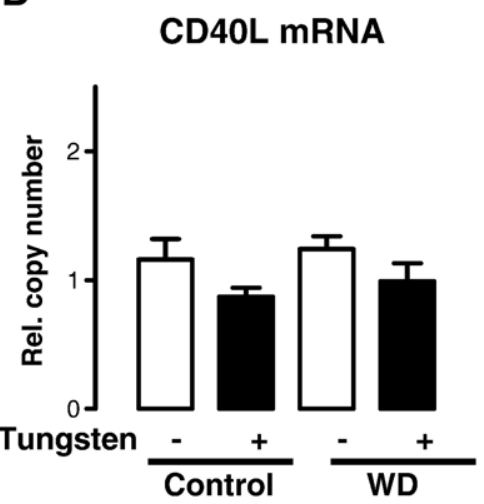

Fig. 1. Effect of a Western-type diet (WD) and tungsten on liver xanthine oxidase/dehydrogenase, CD40 and CD40 ligand (CD40L) mRNA. (A) Relative copy number of liver xanthine dehydrogenase mRNA expression determined by real-time PCR using the $\Delta \Delta \mathrm{CT}$ technique. $n=8,{ }^{*} P<0.05$ tungsten vs no tungsten. (B) Representative Western blot of hepatic xanthine dehydrogenase $(\mathrm{XDH}) /$ xanthine oxidase (XO) protein expression. The XO fragments derive from XDH by proteolysis. (C and D) Relative copy number of liver CD40 (C) and CD40 ligand (D) mRNA expression determined by real-time PCR using the $\Delta \Delta C T$ technique. $n=8, * P<0.05$ control vs Western-type diet. 


\section{Statistics}

All values are means \pm SE. Maximal relaxations were calculated from individual dose-response curves. Statistical analysis was carried out using analysis of variance for repeated measurements followed by the Fisher LSD test, or unpaired $t$ test, if appropriate. Values of $P<0.05$ were considered statistically significant.

\section{Results}

Western-type diet increases liver xanthine oxidase content

A Western-type diet increases liver XDH mRNA expression (Fig. 1A). In the Western blot analysis, a Western-type diet was associated with an increase in the appearance of lower molecular weight fragments of XDH (Fig. 1B). It has been reported previously that these fragments are generated from $\mathrm{XDH}$ by proteolysis in vivo and possess high XO activity [22]. A Western-type diet also increase hepatic CD40 mRNA expression, which was used as a marker of hepatic activation [23]. CD40 ligand (CD154) mRNA expression, in contrast, was not altered by a Western-type diet (Figs. 1C and D).

Tungsten lowers xanthine dehydrogenase expression without affecting plasma lipids

In the blood of control animals, tungsten treatment reduced XO activity by approx $50 \%$ (Fig. 2A), without affecting hepatic $\mathrm{XDH}$ mRNA level. Due to the lipidemic clouding of the plasma and the steatotic transformation of the liver, XO activity measurements were not possible in samples from animals subjected to a Western-type diet. Tungsten reduced the hepatic expression of XDH mRNA in response to a Western-type diet, but had no effect of the proteolytic degradation of XDH to the XO form (Figs. 1A and B). Hepatic CD40 mRNA expression was unaffected by tungsten. Although there was a trend $(P=0.098)$ toward a reduction in hepatic CD40 ligand expression following tungsten treatment, this value did not reach statistical significance (Figs. 1C and D).

A Western-type diet significantly increased the total plasma cholesterol content in $\mathrm{ApoE}^{-/-}$mice (Fig. 2B) and this was due to an increased formation of very-low-density lipoprotein particles (VLDL) as determined by FPLC. Tungsten treatment did not affect total plasma cholesterol content or plasma lipids (Figs. 2C and D).

\section{Tungsten normalized endothelial function during Western-type diet}

Six months of a Western-type diet resulted in a marked increase in aortic superoxide anion production, as determined by dihydroethium fluorescence (Fig. 3) and an attenuation of endothelium-dependent relaxation to acetylcholine (Fig. 4). The effects of a Western-type diet were prevented by feeding tungsten: Endothelium-dependent relaxation in tungsten-treated animals fed a Western-type
A
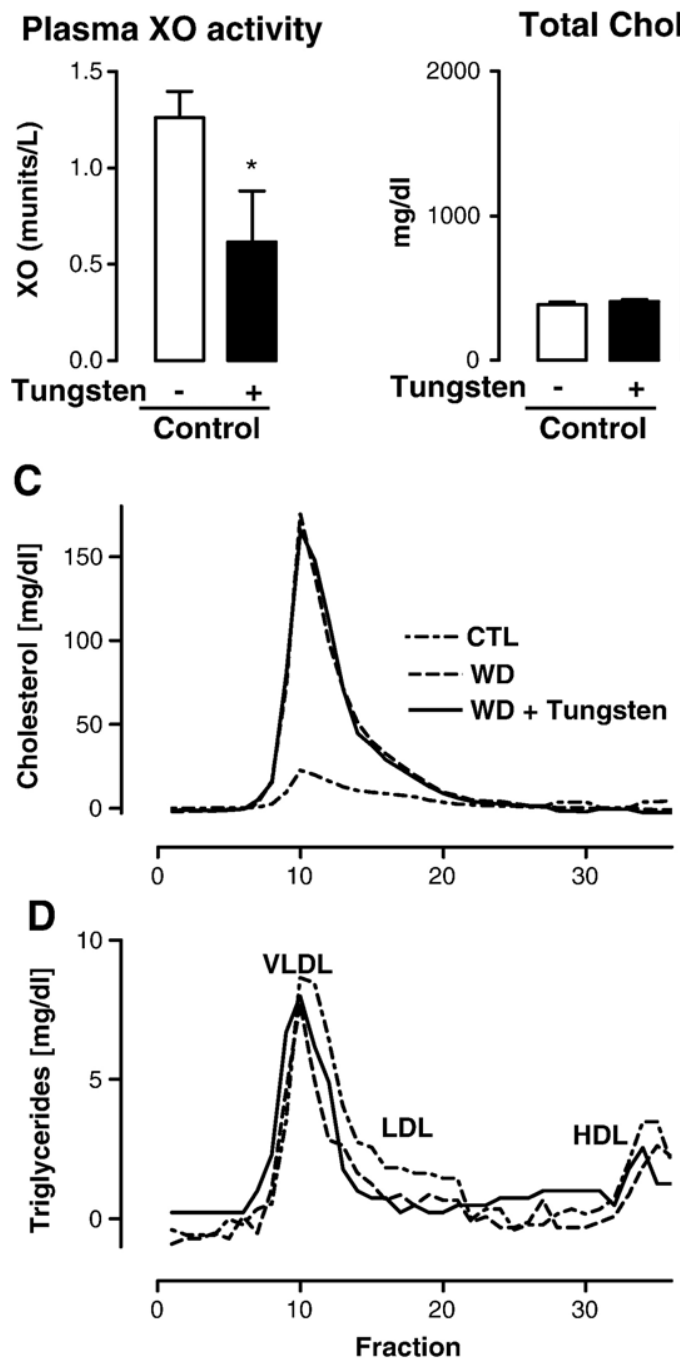

Fig. 2. Effect of tungsten on serum xanthine oxidase activity and lipids. (A and B) Serum samples were prepared from blood samples and $\mathrm{XO}$ activity (A) and total cholesterol (B) were determined using a fluorimetric assay. $n=8, * P<0.05$ vs control. (C and D) Representative tracings of plasma cholesterol content (C) and triglyceride (D) for the determination of lipoprotein content using FPLC. Abbreviations indicate plasma from $\mathrm{ApoE}^{-/-}$on control chow (CTL), Westerntype diet (WD), and Western-type diet and tungsten (WD + tungsten). Labeled peaks correspond to very-low-density lipoproteins (VLDL), low-density lipoproteins (LDL), and high-density lipoproteins (HDL).

diet was identical to that observed in vessels from animals fed a control diet (Fig. 4). Moreover, aortic segments from mice treated with a Western-type diet and tungsten exhibited aortic superoxide anion generation to almost the level observed in control animals (Fig. 3). Tungsten had no effect on aortic endothelium-dependent relaxation (Fig. 4) and radical generation in mice fed a control chow (Fig. 3).

Tungsten treatment attenuates aortic KC mRNA expression during a Western-type diet

A Western-type diet resulted in a significant increase in the aortic expression of the chemokine KC. Tungsten had no effect 

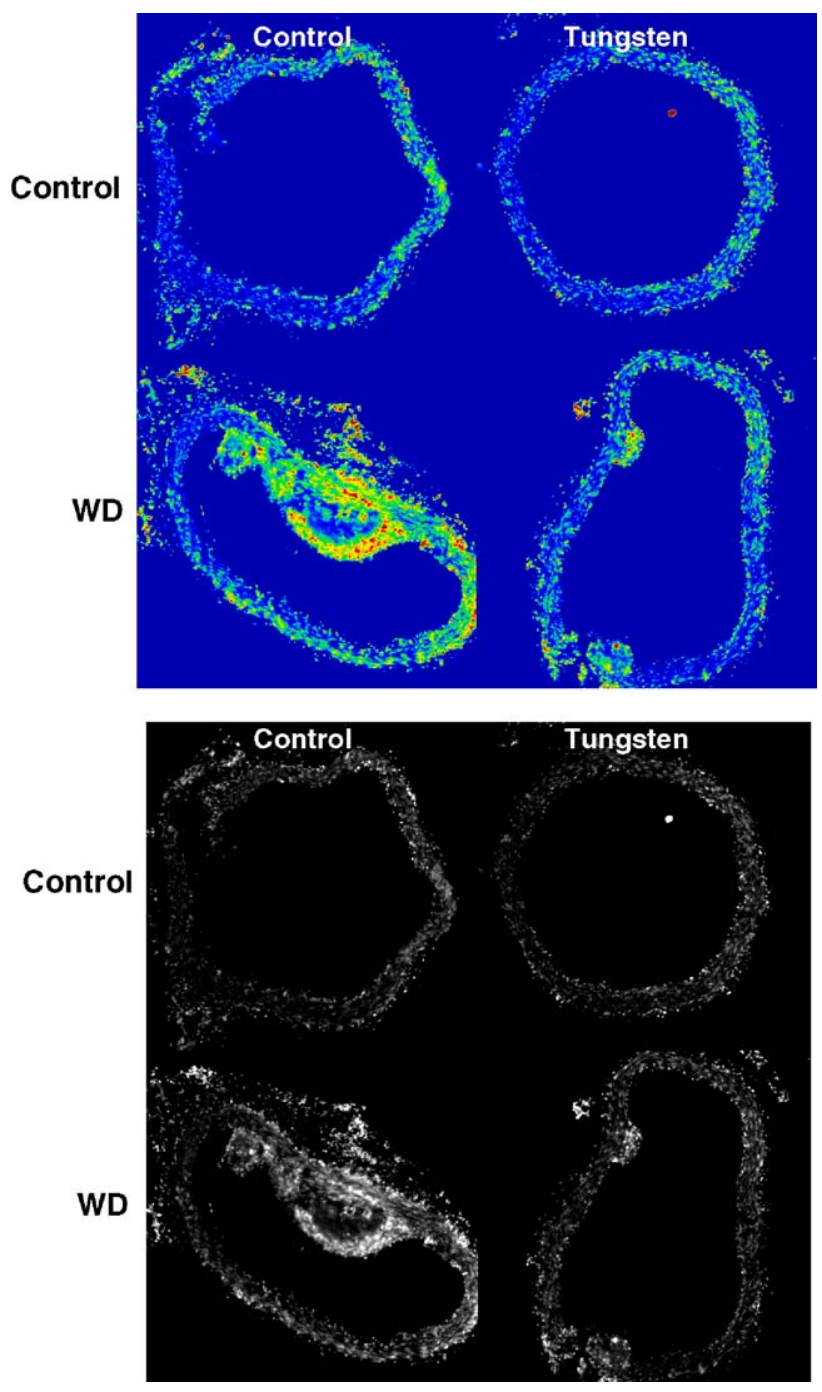

Fig. 3. Effect of Western-type diet (WD) and tungsten on aortic superoxide level. Representative confocal microscopy images of ethidium fluorescence in aortic segments from animals treated with or without a Western-type diet and tungsten. (Top) Pseudo-color images. (Bottom) Gray-scale images.

on aortic $\mathrm{KC}$ mRNA expression in animals receiving a control diet. In animals fed a Western-type diet aortic KC mRNA expression was largely attenuated (Fig. 5).
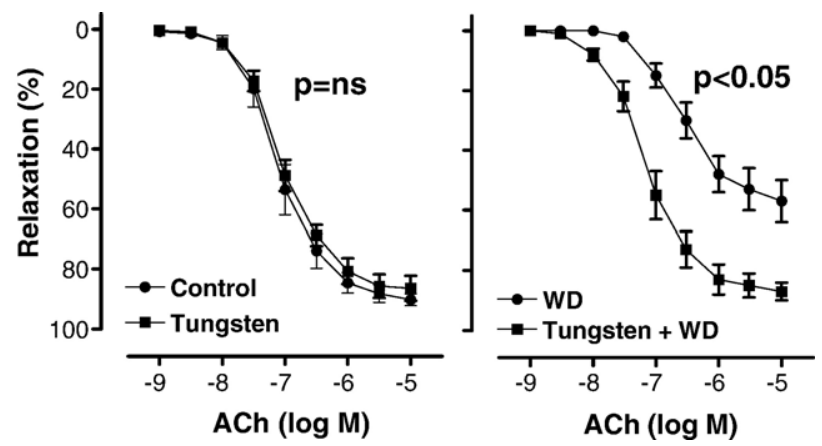

Fig. 4. Effect of a Western-type diet (WD) and tungsten on aortic endotheliumdependent relaxation. Endothelium-dependent relaxation to acetylcholine (ACh) in $\mathrm{ApoE}^{-/-}$mouse aortic segments preconstricted with phenylephrine from animals fed a Western-type or control diet and tungsten. $n=8, * P<0.05$.

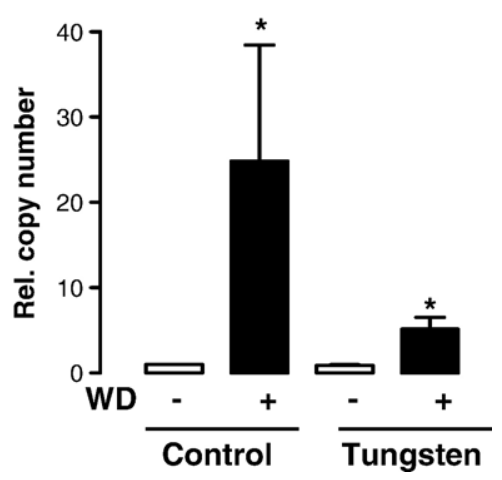

Fig. 5. Effect of a Western-type diet (WD) and tungsten on aortic KC chemokine mRNA expression. Relative copy number of aortic KC mRNA expression determined by real-time PCR using the $\Delta \Delta \mathrm{CT}$ technique and $18 \mathrm{~S}$ as reference gene. $n=5-6, * P<0.05$ vs control.

\section{Tungsten prevents plaque formation in response to a Western-type diet}

$\mathrm{ApoE}^{-/-}$mice spontaneously develop aortic plaques, and plaque area in the abdominal aorta at the age of 9 months was approx $5 \%$ in the strain used. This spontaneous plaque formation was unaffected by tungsten treatment. Six months of a Western-type diet induced a marked increase in aortic plaque formation and this effect was prevented by coadministration of tungsten (Fig. 6).

\section{Discussion}

In this study we report that tungsten treatment prevents aortic superoxide anion generation, attenuates endothelium-dependent
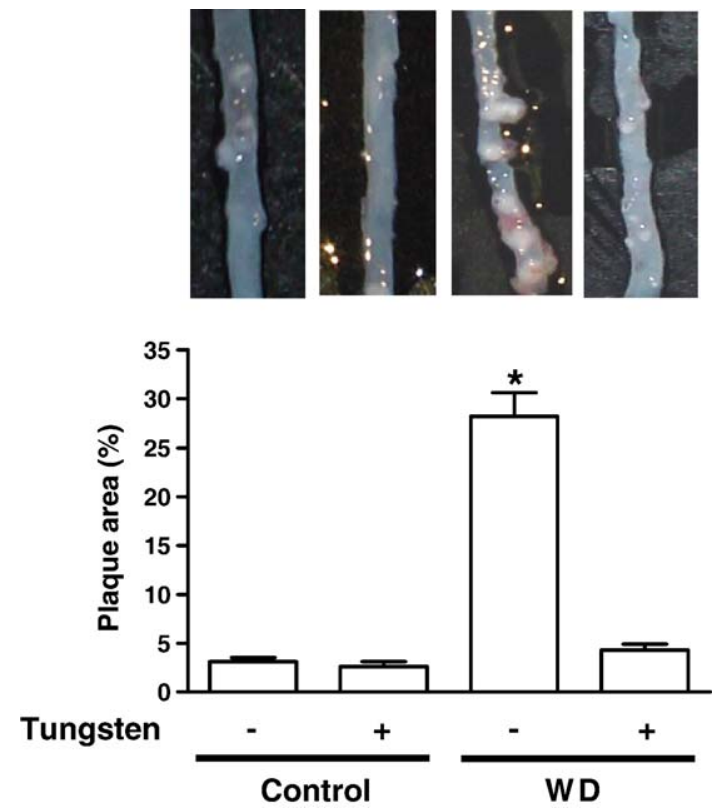

Fig. 6. Development of atherosclerosis in $\mathrm{ApoE}^{-/-}$mice treated with or without a Western-type diet (WD) and tungsten. Representative photographs of the abdominal mouse aorta from animals treated for 6 months and statistical analysis of the planimetry of the aortic plaque area. $n=8, * P<0.05$. 
relaxation, and reduces plaque formation in $\mathrm{ApoE}^{-/}$mice fed a Western-type diet. Tungsten reduced serum XO activity and liver XO mRNA expression but had no effect on proteolytic conversion of $\mathrm{XDH}$ to $\mathrm{XO}$ and plasma lipids.

$\mathrm{XO}$ is a paradigm of a radical-generating enzyme and has been used as a generator system for superoxide and hydrogen peroxide in numerous studies. The biological consequences of extracellular XO-derived radical production are well understood in cell culture systems and there is no doubt that exogenously applied XO in the presence of xanthine elicits an activation of vascular segments and cultured cells compatible with the generation of a atherogenic phenotype. Exogenously applied xanthine/XO stimulates cell growth [24], chemokine and adhesion molecule expression, and scavenges NO, which is thought to have antiatherogenic effects $[10,25]$. In contrast to these data the significance of endogenous $\mathrm{XO}$ for vascular functions are less clear.

In mammals, $\mathrm{XDH} / \mathrm{XO}$ is primarily expressed in the liver, small intestine, and in lactating mammary glands [26,27]. Although expression of XDH mRNA in endothelial cells and macrophages has been reported for some species like mouse and cow [28], XDH mRNA is almost undetectable in human endothelial cells (Schreiber, 2005, unpublished data). Nevertheless, several studies, including this work, demonstrated the effects of XO inhibitors on vascular homeostasis and XO protein is present in vessels from hypercholesterolemic animals [29]. The protein, however, appears to be synthesized in the liver and is secreted into the blood. XO binds to glycosaminoglycans and via this mechanism serum XO is trapped in the vessel wall [29]. Application of heparin, which releases glycocalix-bound proteins, rapidly increases XO plasma levels and improved endothelial function in isolated vessel preparations from hypercholesterolemic animals [29].

The mechanism of lipid-induced hepatic XDH expression has not been studied so far. The promotor of XDH is activated by several inflammatory cytokines [30-32]. A Western-type diet induces nonalcoholic fatty liver disease, also termed steatohepatitis [33], a situation associated with marked hepatic inflammation. The presence of hepatic inflammation was also confirmed in the present study by the demonstration of an induction of CD40 mRNA expression. It is tempting to speculate that the inflammation of the liver, induced by a Western-type diet, mediates the increase in XDH mRNA expression. Moreover, inflammation is a situation associated with oxidative stress. Oxidative stress induces thiol oxidation of proteins. Thiol oxidation of $\mathrm{XDH}$ is the first step in the conversion to $\mathrm{XO}$ which subsequently leads to proteolytic cleavage of the enzyme and the appearance of XO protein fragments in the Western blot analysis [34]. This was also observed in liver tissue in the present study. In line with these observations, we previously reported that a high-fat diet increases renal XDH content and conversion to $\mathrm{XO}$ and that this effect was drastically enhanced by concomitant renal inflammation induced in the Thy1 model [35].

Interestingly, tungsten attenuated the hepatic expression of XDH mRNA in animals fed a Western-type diet. Although it can only be speculated about the underlying mechanism, which is out of the focus of this study, it is possible that a reduction of oxidative stress in the liver through the inhibition of XO by tungsten may contribute to this process.

In rabbits treated with a high-cholesterol diet for 1 month, $\mathrm{XO}$ is the predominant source of $\mathrm{O}_{2}^{-}$and ex vivo inhibition of $\mathrm{XO}$ by oxypurinol normalized vascular $\mathrm{O}_{2}^{-}$production and restored endothelium-dependent relaxation [36]. Also in that particular model, $\mathrm{XO}$ was derived from the liver and bound to the endothelial glycocalix [29], which also may explain the observation that removal of the endothelium by denudation decreased vascular $\mathrm{O}_{2}^{-}$production [36]. Once atherosclerosis has developed, vascular $\mathrm{O}_{2}^{-}$production remained elevated, but $\mathrm{XO}$ contributes less to the overall radical production [37]. It is likely that the NADPH oxidase, which is present in foam cells and leukocytes, is an important source of radicals in advanced atherosclerotic plaques $[38,39]$. Indeed, inhibition of XO had almost no effect on the $\mathrm{O}_{2}^{-}$production measured by lucigenin chemiluminescence in the atherosclerosic aorta of $\mathrm{ApoE}^{-/}$ mice fed a Western-type diet (R. Brandes, unpublished observation).

In the present study, tungsten was used to inhibit XO. This approach was chosen, as the most commonly used XO inhibitor allopurinol is nephrotoxic in mice [13]. In fact, also an allopurinol treatment group was initially included in this study, but the mice rapidly developed renal failure and stones in the kidney and the bladder forcing termination of this part of the study. It is, however, important to realize that this side effect of allopurinol is not a consequence of the accumulation of purines but rather specific for allopurinol [13]. As a consequence, the present study heavily relies on the data obtained with tungsten. There is little doubt that tungsten is a reliable XO inhibitor, as also observed in the present study. Tungsten, however, also inhibits aldehyde oxidase and sulfite oxidase which are other molybdenum-containing enzymes in the body [40]. As the role of these two proteins for vascular homeostasis has not at all been studied so far, the effects observed in the present study cannot be attributed to XO inhibition with absolute certainty.

The most important observation of the present study was that atherosclerosis development in $\mathrm{ApoE}^{-/-}$mice fed a Westerntype diet was largely attenuated by tungsten. A Western-type diet also increased the aortic $\mathrm{KC}$ expression and this effect was reduced by tungsten. It is attractive to speculate that aortic $\mathrm{KC}$ induction is mediated by xanthine oxidase and subsequent oxidative stress and that inhibition of this enzyme prevents aortic $\mathrm{KC}$ induction, leading to less atherosclerosis. Indeed, $\mathrm{KC}$ is known to be an essential chemokine for monocyte attraction in mice [41]. Nevertheless, $\mathrm{KC}$ is a classical chemokine, which is induced by inflammation and the present data indicate that a Western-type diet is associated with significant inflammatory activation of the liver. Interestingly, a Western-diet also elicited hepatic $\mathrm{KC}$ expression, but this was unaffected by tungsten (data not shown), suggesting that the mechanisms leading to $\mathrm{KC}$ expression vary between aorta and liver. Direct inflammatory induction may predominate in the liver, whereas in the aorta xanthine oxidase could be involved in the induction of the chemokine. 
In the present study, atherosclerosis was associated with increased vascular superoxide anion generation and endothelial dysfunction. Based on the study design, it can, however, not be dissected whether endothelial dysfunction and oxidative stress are cause or consequence of atherosclerosis. In this regard, the observations that tungsten prevented the Western-type dietinduced effects on all three readouts cannot serve as proof for an involvement of oxidative stress and endothelial dysfunction in atherosclerosis development, although it is certainly attractive to speculate that, at least in mice, this is indeed the case.

In conclusion, a Western-type diet increases hepatic XO expression and leads to atherosclerosis, vascular oxidative stress, and endothelial dysfunction. The vascular effects of a Western-type diet are prevented by the inhibition of XO using tungsten, suggesting a pathophysiological role of enzymes inhibited by tungsten, such as $\mathrm{XO}$, for vascular disease induced by high-fat intake.

\section{Acknowledgments}

The authors thank Sina Bätz and Tanja Megies for excellent technical assistance. This study was supported by a grant from the Deutsche Forschungsgemeinschaft to R.P.B. (BR1839/2-3).

\section{References}

[1] Stocker, R.; Keaney, J. F., Jr. Role of oxidative modifications in atherosclerosis. Physiol. Rev. 84:1381-1478; 2004.

[2] Taniyama, Y.; Griendling, K. K. Reactive oxygen species in the vasculature: molecular and cellular mechanisms. Hypertension 42: 1075-1081; 2003.

[3] Hasnain, B. I.; Mooradian, A. D. Recent trials of antioxidant therapy: what should we be telling our patients? Cleve. Clin. J. Med. 71:327-334; 2004.

[4] Morris, C. D.; Carson, S. Routine vitamin supplementation to prevent cardiovascular disease: a summary of the evidence for the U.S. Preventive Services Task Force. Ann. Intern. Med. 139:56-70; 2003.

[5] Patterson, C.; Ruef, J.; Madamanchi, N. R.; Barry-Lane, P.; Hu, Z.; Horaist, C.; Ballinger, C. A.; Brasier, A. R.; Bode, C.; Runge, M. S. Stimulation of a vascular smooth muscle cell $\mathrm{NAD}(\mathrm{P}) \mathrm{H}$ oxidase by thrombin. Evidence that 47 (phox) may participate in forming this oxidase in vitro and in vivo. J. Biol. Chem. 274:19814-19822; 1999.

[6] Hsich, E.; Segal, B. H.; Pagano, P. J.; Rey, F. E.; Paigen, B.; Deleonardis, J.; Hoyt, R. F.; Holland, S. M.; Finkel, T. Vascular effects following homozygous disruption of p47(phox) : an essential component of NADPH oxidase. Circulation 101:1234-1236; 2000.

[7] Kirk, E. A.; Dinauer, M. C.; Rosen, H.; Chait, A.; Heinecke, J. W.; LeBoeuf, R. C. Impaired superoxide production due to a deficiency in phagocyte NADPH oxidase fails to inhibit atherosclerosis in mice. Arterioscler. Thromb. Vasc. Biol. 20:1529-1535; 2000.

[8] Povoa, H., Jr.; Sa, L. D.; Lessa, V. M. Xanthine oxidase and triglycerides in serum of patients with hyperlipoproteinemia, type IV. Biomed. Biochim. Acta 43:1201-1203; 1984.

[9] Janssen, M.; de Jong, J. W.; Pasini, E.; Ferrari, R. Myocardial xanthine oxidoreductase activity in hypertensive and hypercholesterolemic rats. Cardioscience 4:25-29; 1993.

[10] Berry, C. E.; Hare, J. M. Xanthine oxidoreductase and cardiovascular disease: molecular mechanisms and pathophysiological implications. J. Physiol. 555:589-606; 2004.

[11] Meir, K. S.; Leitersdorf, E. Atherosclerosis in the apolipoprotein-Edeficient mouse: a decade of progress. Arterioscler.Thromb. Vasc. Biol. 24:1006-1014; 2004.

[12] Vorbach, C.; Scriven, A.; Capecchi, M. R. The housekeeping gene xanthine oxidoreductase is necessary for milk fat droplet enveloping and secretion: gene sharing in the lactating mammary gland. Genes Dev. 16:3223-3235; 2002.

[13] Horiuchi, H.; Ota, M.; Nishimura, S.; Kaneko, H.; Kasahara, Y.; Ohta, T.; Komoriya, K. Allopurinol induces renal toxicity by impairing pyrimidine metabolism in mice. Life Sci. 66:2051-2070; 2000.

[14] Owen, E. C.; Dundas, I. Diminution of xanthine oxidase in goat milk after subcutaneous injection of sodium tungstate (Na2WO4.2H2O). Proc. Nutr. Soc. 28:59A; 1969.

[15] Gwinner, W.; Plasger, J.; Brandes, R. P.; Kubat, B.; Schulze, M.; Regele, H.; Kerjaschki, D.; Olbricht, C. J.; Koch, K. M. Role of xanthine oxidase in passive Heymann nephritis in rats. J. Am. Soc. Nephrol. 10:538-544; 1999.

[16] Strittmatter, C. F. Studies on avian xanthine dehydrogenases. Properties and patterns of appearance during development. J. Biol. Chem. 240:2557-2564; 1965.

[17] Jung, O.; Marklund, S. L.; Geiger, H.; Pedrazzini, T.; Busse, R.; Brandes, R. P. Extracellular superoxide dismutase is a major determinant of nitric oxide bioavailability: in vivo and ex vivo evidence from ecSOD-deficient mice. Circ. Res. 93:622-629; 2003.

[18] Brandes, R. P.; Miller, F. J.; Beer, S.; Haendeler, J.; Hoffmann, J.; Ha, T.; Holland, S. M.; Gorlach, A.; Busse, R. The vascular NADPH oxidase subunit $\mathrm{p} 47 \mathrm{phox}$ is involved in redox- mediated gene expression. Free Radic. Biol. Med. 32:1116-1122; 2002.

[19] McManaman, J. L.; Neville, M. C.; Wright, R. M. Mouse mammary gland xanthine oxidoreductase: purification, characterization, and regulation. Arch. Biochem. Biophys. 371:308-316; 1999.

[20] Beckman, J. S.; Parks, D. A.; Pearson, J. D.; Marshall, P. A.; Freeman, B. A. A sensitive fluorometric assay for measuring xanthine dehydrogenase and oxidase in tissues. Free Radic. Biol. Med. 6: 607-615; 1989.

[21] Shiri-Sverdlov, R.; Wouters, K.; van Gorp, P. J.; Gijbels, M. J.; Noel, B.; Buffat, L.; Staels, B.; Maeda, N.; van Bilsen, M.; Hofker, M. H. Early dietinduced non-alcoholic steatohepatitis in APOE2 knock-in mice an prevention by fibrates. J. Hepatol. 44:732-741; 2006.

[22] Amaya, Y.; Yamazaki, K.; Sato, M.; Noda, K.; Nishino, T.; Nishino, T. Proteolytic conversion of xanthine dehydrogenase from the NADdependent type to the O2-dependent type. Amino acid sequence of rat liver xanthine dehydrogenase and identification of the cleavage sites of the enzyme protein during irreversible conversion by trypsin. J. Biol. Chem. 265:14170-14175; 1990.

[23] Danese, S.; Sans, M.; Fiocchi, C. The CD40/CD40L costimulatory pathway in inflammatory bowel disease. Gut 53:1035-1043; 2004.

[24] Rao, G. N.; Berk, B. C. Active oxygen species stimulate vascular smooth muscle cell growth and proto-oncogene expression. Circ. Res. 70: 593-599; 1992.

[25] Gryglewski, R. J.; Palmer, R. M.; Moncada, S. Superoxide anion is involved in the breakdown of endothelium-derived vascular relaxing factor. Nature 320:454-456; 1986.

[26] Parks, D. A.; Granger, D. N. Xanthine oxidase: biochemistry, distribution and physiology. Acta Physiol. Scand. Suppl. 548:87-99; 1986.

[27] Linder, N.; Rapola, J.; Raivio, K. O. Cellular expression of xanthine oxidoreductase protein in normal human tissues. Lab. Invest. 79:967-974; 1999.

[28] McNally, J. S.; Davis, M. E.; Giddens, D. P.; Saha, A.; Hwang, J.; Dikalov, S.; Jo, H.; Harrison, D. G. Role of xanthine oxidoreductase and NAD(P)H oxidase in endothelial superoxide production in response to oscillatory shear stress. Am. J. Physiol. Heart Circ. Physiol. 285:H2290-H2297; 2003.

[29] White, C. R.; Darley-Usmar, V.; Berrington, W. R.; McAdams, M.; Gore, J. R.; Thompson, J.; Parks, D. A.; Tarpey, M. M.; Freeman, B. A. Circulating plasma xanthine oxidase contributes to vascular dysfunction in hypercholesterolemic rabbits. Proc. Natl. Acad. Sci. USA 93:8745-8749; 1996.

[30] Terao, M.; Cazzaniga, G.; Ghezzi, P.; Bianchi, M.; Falciani, F.; Perani, P.; Garattini, E. Molecular cloning of a cDNA coding for mouse liver xanthine dehydrogenase. Regulation of its transcript by interferons in vivo. Biochem. J. 283 (Pt 3):863-870; 1992.

[31] Chow, C. W.; Clark, M.; Rinaldo, J.; Chalkley, R. Identification of the rat xanthine dehydrogenase/oxidase promoter. Nucleic Acids Res. 22: 1846-1854; 1994. 
[32] Pfeffer, K. D.; Huecksteadt, T. P.; Hoidal, J. R. Xanthine dehydrogenase and xanthine oxidase activity and gene expression in renal epithelial cells. Cytokine and steroid regulation. J. Immunol. 153:1789-1797; 1994.

[33] Ludwig, J.; McGill, D. B.; Lindor, K. D. Review: nonalcoholic steatohepatitis. J. Gastroenterol. Hepatol. 12:398-403; 1997.

[34] Nishino, T.; Nishino, T. The conversion from the dehydrogenase type to the oxidase type of rat liver xanthine dehydrogenase by modification of cysteine residues with fluorodinitrobenzene. J. Biol. Chem. 272: 29859-29864; 1997.

[35] Scheuer, H.; Gwinner, W.; Hohbach, J.; Grone, E. F.; Brandes, R. P.; Malle, E.; Olbricht, C. J.; Walli, A. K.; Grone, H. J. Oxidant stress in hyperlipidemia-induced renal damage. Am. J. Physiol. Renal Physiol. 278:F63-F74; 2000.

[36] Ohara, Y.; Peterson, T. E.; Harrison, D. G. Hypercholesterolemia increases endothelial superoxide anion production. J. Clin. Invest. 91:2546-2551; 1993.

[37] Mugge, A.; Brandes, R. P.; Boger, R. H.; Dwenger, A.; Bode-Boger, S.; Kienke, S.; Frolich, J. C.; Lichtlen, P. R. Vascular release of superoxide radicals is enhanced in hypercholesterolemic rabbits. J. Cardiovasc. Pharmacol. 24:994-998; 1994.
[38] Azumi, H.; Inoue, N.; Ohashi, Y.; Terashima, M.; Mori, T.; Fujita, H.; Awano, K.; Kobayashi, K.; Maeda, K.; Hata, K.; Shinke, T.; Kobayashi, S.; Hirata, K.; Kawashima, S.; Itabe, H.; Hayashi, Y.; Imajoh-Ohmi, S.; Itoh, H.; Yokoyama, M. Superoxide generation in directional coronary atherectomy specimens of patients with angina pectoris: important role of NAD $(\mathrm{P}) \mathrm{H}$ oxidase. Arterioscler.Thromb.Vasc. Biol. 22:1838-1844; 2002.

[39] Warnholtz, A.; Nickenig, G.; Schulz, E.; Macharzina, R.; Brasen, J. H.; Skatchkov, M.; Heitzer, T.; Stasch, J. P.; Griendling, K. K.; Harrison, D. G.; Bohm, M.; Meinertz, T.; Munzel, T. Increased NADH-oxidase-mediated superoxide production in the early stages of atherosclerosis: evidence for involvement of the renin-angiotensin system. Circulation 99:2027-2033; 1999.

[40] Kisker, C.; Schindelin, H.; Rees, D. C. Molybdenum-cofactor-containing enzymes: structure and mechanism. Аnпu. Rev. Biochem. 66:233-267; 1997.

[41] Huo, Y.; Weber, C.; Forlow, S. B.; Sperandio, M.; Thatte, J.; Mack, M.; Jung, S.; Littman, D. R.; Ley, K. The chemokine KC, but not monocyte chemoattractant protein-1, triggers monocyte arrest on early atherosclerotic endothelium. J. Clin. Invest. 108:1307-1314; 2001. 